\title{
Experimental models for the study of neuropathic pain
}

\author{
Modelos experimentais para o estudo da dor neuropática \\ Angela Maria Sousa ${ }^{1}$, Gustavo Veloso Lages ${ }^{2}$, Carla Leal Pereira ${ }^{3}$, Alexandre Slullitel ${ }^{4}$
}

\section{ABSTRACT}

BACKGROUND AND OBJECTIVES: Ideal models should reproduce just sensory deficits, such as alodynia, hyperalgesia and spontaneous pain for short periods. There are different types of animal models to evaluate different neuropathic pain etiologies and manifestations. Some models study neuropathic pain peripheral mechanisms and other study its central mechanisms. This review focuses on animal models most commonly used for neuropathic pain research.

CONTENTS: Animal models based on peripheral nerves ligation which are more commonly used are described. From all models described in this review, spared nerve injury is that producing more reproducible behavioral abnormalities for a longer period, while chronic sciatic nerve compression produces behavioral signs of less predictable painful neuropathies. Spinal hemisection and cytokines-induced spinal injury are the models of choice for the study of central pain mechanisms. Other specific models are used for the study of the specific etiology of pain.

CONCLUSION: Since neuropathic pain is multifactorial, different neuropathic pain animal models were developed throughout the years, which have been critical for the study of neuropathic pain, since much of current knowledge comes from studies with rats and mice. Current animal models need to be further refined and more efforts should be made to determine which animal models may be more predictive, with less biases and more complex and objective analysis parameters.

Keywords: Experimental models of neuropathic pain, Neuropathic pain.

\section{RESUMO}

JUSTIFICATIVA E OBJETIVOS: Os modelos ideais deveriam reproduzir apenas déficits sensitivos, como alodínea, hiperalgesia e dor espontânea por curtos períodos de tempo. Existem diversos tipos de modelos animais, que avaliam as diversas etiologias e manifestaçōes da dor neuropática. Alguns modelos estudam os mecanismos periféricos e outros estudam mecanismos centrais da dor neuropática. Esta revisăo enfoca os modelos animais mais comumente utilizados para pesquisa em dor neuropática.

CONTEÚDO: São descritos modelos animais baseados em ligadura de nervos periféricos que são mais comumente empregados. De todos os modelos descritos nesta revisão, a lesão poupadora de nervo é aquela que produz anormalidades comportamentais mais reprodutíveis, por um período mais longo, ao passo que a constrição crônica do ciático produz sinais comportamentais de neuropatia dolorosas menos previsíveis. Hemisecçáo espinhal e lesão espinhal induzida por citocinas são os modelos de escolha para estudar mecanismos de dor central. Outros modelos específicos são utilizados para estudo da etiologia específica da condição dolorosa.

CONCLUSÃO: Como a dor neuropática é multifatorial, diferentes modelos animais de dor neuropática foram desenvolvidos ao longo dos anos que têm sido fundamentais para o estudo da dor neuropática, uma vez que muito do conheci-

1. Universidade de São Paulo, Faculdade de Medicina, Anestesiologista, Chefe de Equipe de Dor do Instituto do Câncer do Estado de São Paulo, São Paulo, SP, Brasil.

2. Hospital Santa Casa, Hospital Dilson Godinho, Departamento de Neurocirurgia, Montes Claros, MG. 3. Hospital São Luís, Anestesiologista, Supervisor Responsável pelo serviço de dor - Unidade Brasil. Sáo Paulo, SP, Brasil.

4. Hospital Santa Paula, Anestesiologista, Corresponsável pelo Centro de Ensino e Treinamento, Hospital Campo Limpo, São Paulo, SP, Brasil.

Conflict of interests: none - Sponsoring sources: none.

\section{Correspondence to:}

Av. Dr. Enéas de Carvalho Aguiar, 255, $8^{\circ}$ andar

05403-000 Sáo Paulo, SP, Brasil.

E-mail: angela.sousa@icesp.org.b

(c) Sociedade Brasileira para o Estudo da Dor mento atual provém de estudos em ratos e camundongos. São necessários maiores refinamentos nos modelos animais atualmente empregados e mais esforços para determinar quais modelos animais podem ser mais preditivos, com menos vieses e com parâmetros de análises mais complexos e objetivos.

Descritores: Dor neuropática, Modelos experimentais de dor neuropática.

\section{INTRODUCTION}

Neuropathic pain (NP) is characterized by sensory abnormalities such as abnormal unpleasant sensation (dysesthesia), increased intensity of response to painful stimuli (hyperalgesia) and pain in response to normally painless stimuli (allodynia) ${ }^{1}$.

Most experimental NP models were developed as from peripheral traumatic, metabolic or toxic injuries ${ }^{2}$. Such models are relevant for the study of peripheral disorders in humans (neuropathies, plexopathies and radiculopathies), which represent a considerable percentage of NP-inducing diseases. Diabetes and alcoholism, for example, promote sensory disorders which may induce pain by painful peripheral neuropathy ${ }^{2}$.

In cancer patients, in addition to tumor growth and compression of nervous structures causing tissue injury, treatment itself may induce $\mathrm{NP}^{3}$. Global incidence of chemotherapy-induced neuropathy is high, between 20 and $100 \%$, because more effective drugs to treat solid tumors, in high doses, induce peripheral neuropathy as secondary effect ${ }^{4}$. As opposed to diabetes-related NP, which starts on feet and then affects hands in a period of time varying from months to years, chemotherapy-induced NP may simultaneously appear on hands and feet ${ }^{4}$.

Experimental evaluation of NP in humans is complex, because most stimuli necessary to produce pain also produce neural injury. So, animal studies are needed to understand mechanisms involved with $\mathrm{NP}^{2}$.

\section{NEUROPATHIC PAIN MODELS IN ANIMALS}

Ideal models should produce just sensory deficits, such as allodynia, hyperalgesia and spontaneous pain for short periods of time.

There are different animal models to evaluate different NP etiologies and manifestations (Table 1$)^{2}$. Some models study peripheral NP mechanisms and others study central mechanisms ${ }^{2}$. This review focuses on most commonly used animal models to study NP.

\section{Peripheral nerves injury}

Axotomy of a variable portion of nervous fibers has become a primordial technique to generate pain behaviors in animals, being performed in rhizotomy ${ }^{5}$, partial sciatic nerve ligation (PSL), L5 spinal nerve ligation (SNL) and spared nerve injury (SNI). In all these models, injured animals develop self-protection behaviors and have exaggerated reactions to mechanical (allodynia) and thermal stimuli².

\section{Axotomy}

These are extensive injuries coursing with complete sciatic nerve transection in the medial region of the thigh. Animal is anesthetized, common sciatic nerve is exposed and approximately $5 \mathrm{~mm}$ of the nerve are removed. Adjacent saphenous nerve is also injured, inducing complete limb denervation. Animal develops painful anesthesia and autoctomy (self-mutilation) behavior. In this model, animals are monitored for the extension of the injury caused by autoctomy. However, the interpretation of the mutilation is ambiguous. Although being considered by some investigators as response to mutilated limb chronic pain, it is considered by others just as a reaction to complete anesthesia of deafferented limb or to local pain induced by the injury ${ }^{2}$

Such model was replaced by milder injuries to such nerves, which are equally effective to induce NP behaviors in animals. 
Table 1. Neuropathic pain models ${ }^{2}$

\begin{tabular}{|c|c|c|}
\hline Model name & Type of injury & Animal \\
\hline Axotomy & Complete sciatic section & Rat \\
\hline Chronic sciatic constriction & 4 ligatures around the nerve & Rats and mice \\
\hline Partial sciatic ligature & Ligature of $1 / 3$ to $1 / 2$ the nerve & Rats and mice \\
\hline Spinal roots ligation & $\begin{array}{l}\text { 1. Ligation of } L 5 / L 6 \\
\text { 2. Ligation of } L 7\end{array}$ & $\begin{array}{l}\text { Rats } \\
\text { Monkeys }\end{array}$ \\
\hline Nerve-sparing injury & Tibial and peroneal axotomy & Rats and mice \\
\hline Tibial and sural nerve transection & Tibial and sural axotomy & Rats \\
\hline Common peroneal ligation & Common peroneal ligation & Mice \\
\hline Sciatic cryoneurolysis & Nerve freezing & Rats \\
\hline Caudal trunk resection & Caudal trunk resection & Rats and mice \\
\hline Sciatic inflammatory neuritis & Zymozan injection, TNF around the nerve & Rats and mice \\
\hline Balloon-induced sciatic injury & Implant of polyethylene balloon around the nerve & Rats and mice \\
\hline Laser-induced sciatic injury & Decreased blood flow to the nerve mediated by radiation & Rats \\
\hline Spinal injury by contusion & A weight is dropped on exposed spinal cord & Rats and mice \\
\hline Excitotoxic spinal cord injury & Spinal injection of aminoacids & Rats and mice \\
\hline Spinal hemisection & Laminectomy of T11-T12 & Rats \\
\hline $\begin{array}{l}\text { Drug-induced } \\
\text { 1. antineoplastic drugs (vincristine, cisplatin, } \\
\text { oxaliplatin, paclitaxel) } \\
\text { 2. anti-HIV (2,3- dideoxycytidine, didanosine) }\end{array}$ & Direct drug injury to peripheral nerves & 1.Rats, mice, Guinea pigs \\
\hline $\begin{array}{l}\text { Diabetes-induced neuropathy } \\
\text { 1. induced by streptozocin } \\
\text { 2. genetic models }\end{array}$ & Persistent changes in nerves induced by hyperglycemia & Rats and mice \\
\hline Bone pain models & Inoculation of cancer cells in bones & Rats and mice \\
\hline HIV-induced neuropathy & Inoculation of HIV gp120 protein in sciatic nerve & Rats \\
\hline Postherpetic neuralgia & Injection of viral cells & Rats \\
\hline Alcoholic neuropathy & Ethanol administration for long periods & Rats \\
\hline Pyridoxine-induced neuropathy & Administration of high doses of pyridoxine for long periods & Dogs and rats \\
\hline Trigeminal neuralgia & Trigeminal compression; chronic infraorbitary nerve constriction & Rats \\
\hline Orofacial pain & Formalin of carrageenin injection in temporomandibular joint and jaw & Rats and mice \\
\hline Acrylamide-induced & Administration of acrylamide for long periods & Rats \\
\hline
\end{tabular}

\section{Chronic sciatic nerve constriction (loose sciatic ligation)}

Under anesthesia, an incision of approximately $3 \mathrm{~cm}$ is made on the skin covering the area between gluteus and femoral biceps muscles of the hind paw of rats. Common sciatic nerve is exposed and four loose knots with chrome plated Catgug 4-0 are tied around the nerve at a distance of $5 \mathrm{~mm}$ between them ${ }^{6}$. Animals develop behaviors resembling NP in humans by protecting the injured limb (animal tries to hide the paw) suggesting spontaneous pain. In addition, there is pain evoked by warmth and mechanical stimulation, characterizing thermal and mechanical hyperalgesia, chemical hyperactivity and allodynia to cold, which are detected one week after injury. Pain mechanism may be explained by immune reaction triggered by suture thread, causing nerve edema and compression, in addition to axotomy and Wallerian degeneration.

Electrophysiological studies in this model have revealed slower conduction velocity and histopathology shows major injury in myelinated fibers, A delta fibers and unmyelinated $\mathrm{C}$ fibers, which are responsible for pain ${ }^{6}$.

Peripheral mononeuropathy is similar to that of causalgia and complex regional pain syndrome in humans.

\section{Partial sciatic nerve ligation (Seltzer's model) ${ }^{7}$}

The sciatic nerve is exposed in upper thigh. The dorsal third (or half) of the sciatic nerve is tied by a silk thread 8-0 with a loose knot at the region distal to the point where posterior branches of semitendinous biceps emerge. After injury, animals develop protection behavior and licking of the affected limb, suggesting spontaneous pain. Other behavioral changes are also reported in this model one week after surgery and lasting for approximately six weeks.
Seltzer's model $^{7}$ represents pain not mediated by sympathetic in the first postoperative week. In further weeks, however, there is change in the sympathetic nervous system in this model.

Hyperalgesia duration depends on the type of suture material. This is a good model to study causalgia.

\section{Spinal roots ligation $(\mathrm{SNL})^{8}$}

Animals are anesthetized and a $2 \mathrm{~cm}$ incision is made at the height of the posterior iliac crest to allow access to rats' lumbar spine roots. Spinal nerves L 5 and L6 are identified and carefully dissected to release the root of L4 (which is not involved in the ligation) and a silk thread 6.0 is used to promote loose ligation of mentioned roots.

Animals develop mechanical allodynia to cold, thermal hyperalgesia and spontaneous pain 24 to 48 hours after surgery, which persist for 10 to 16 weeks ${ }^{8}$. It may be considered an animal model of pain mediated by sympathetic, since sympathetic block relieves hyperalgesia.

As compared to $\mathrm{CCI}^{6}$ and $\mathrm{PSL}^{7}$, nervous ligation extension and site are more consistent. In addition, spinal segments are preserved intact while others are being injured, thus closer to reality. Drawback is larger surgical extension.

\section{Spared nerve injury (SNL) ${ }^{9}$}

Animals are anesthetized and an incision is performed on femoral biceps of right hind paw of rats. Sciatic nerve and its three terminal branches are exposed: sural, common fibular and tibial. Tibial and common peroneal are tied with a silk thread 5-0 and then they are sectioned at $2 \mathrm{~mm}$ of their end. Sural nerve is not manipulated, that is, it is spared. The other two nerves (tibial and 
common fibular) are sectioned and that is why the technique is called spared nerve injury?.

The response to nociceptive and non-nociceptive stimuli is increased in the territory of the ipsilateral sural nerve and at a lesser extent, in the territory of the saphenous nerve.

Pain induced by this model is independent from sympathetic nervous system and, differently from other models, allows the comparison of thermal and mechanical sensitivity of non-injured territories close to injured areas. This way, it is possible to evaluate the contribution of injured primary sensory afferent neurons to hypersensitivity ${ }^{2}$.

Mechanical and thermal hyperalgesia are present 4 days after surgery and persist for several weeks, up to 6 month $^{4}$.

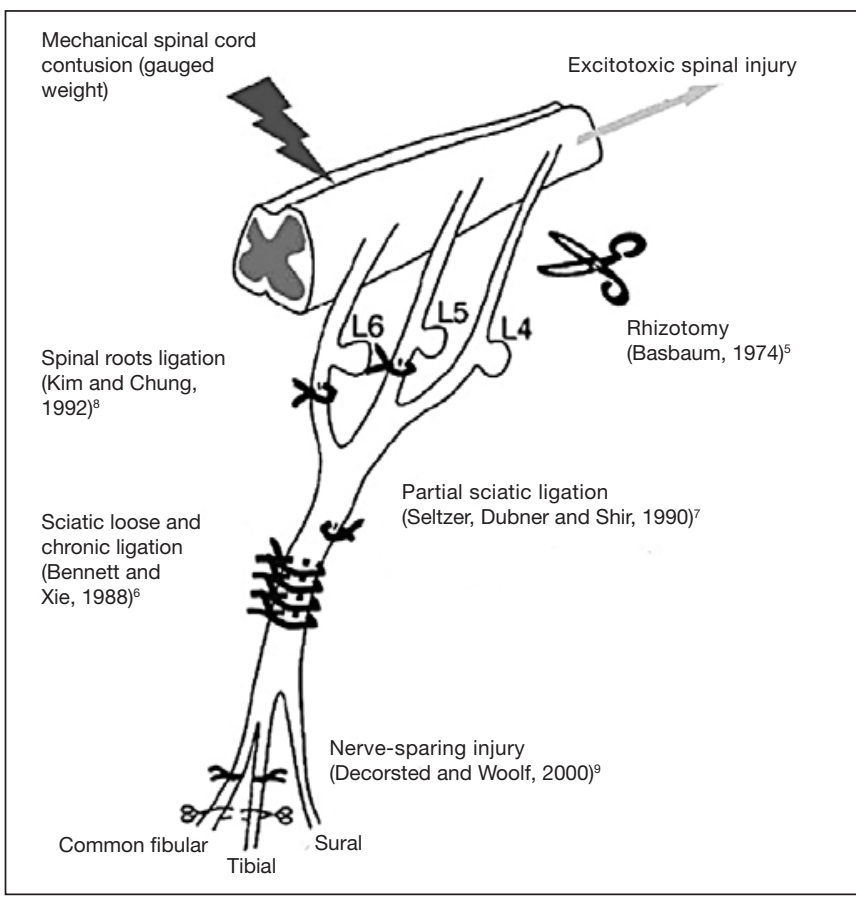

Figure 1. Experimental model of neuropathic pain. Roots ligation (SNL), partial nerve ligation (PNL), chronic nerve constriction (CNC), rhizotomy, spinal cord mechanical contusion, spared nerve injury. Adapted ${ }^{16}$

\section{CENTRAL INJURIES}

\section{Contusion models}

Most spinal injuries in humans are result of fracture/luxations induced by compressive contusions. So, models resulting in nervous tissue contusions seem to be relevant to evaluate clinical phenomena. In the model described by Allen ${ }^{10}$, spinal cord is exposed by laminectomy in the thoracolumbar region and a weight is left to fall over spinal cord of dogs. As a consequence, there is paraplegia and complete segmental necrosis. Several different contusion mod$\mathrm{els}^{11-13}$ were developed since then, in the attempt to control injury level. New "pendulums" were projected using the force of the impact rather than tissue displacement.

\section{EXCITOTOXIC MODELS}

\section{Diabetic neuropathy}

\section{Streptozocin-induced neuropathy $y^{14}$}

Streptozocin (2-desoxi-2 (3-methyl-3-nitro shureido)-D-glucopyranose) is an anti-cancer agent clinically classified as antibiotic and chemically analog to nitrosoureas chemotherapeutic drugs. Intravenous injection of $60 \mathrm{mg} / \mathrm{kg}$ streptozocin in rats induces diabetes after three days, due to beta cells destruction. This model is used to study diabetes-induced neuropathy.

However, animals develop other metabolic disorders caused by hyperglycemia, such as ketoacidosis, lipid metabolism changes, widespread physical weakness (decreased growth and motor activity, lethargy, bladder distention, polyuria and diarrhea). Some of those symptoms complicate data interpretation in animal pain studies.

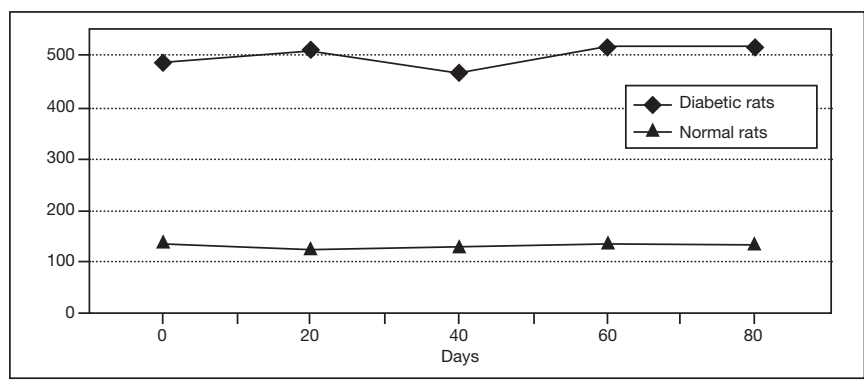

Figure 2. Glycemia of animals receiving intravenous streptozocin versus normal animals. Adapted ${ }^{14}$

Chemotherapy-induced neuropathy ${ }^{2}$

\section{Vincristine}

Vincristine is a purified alkaloid extracted from the Linn pervinca plant from the Apocynaceae family.

Different animal models of vincristine-induced neuropathy were developed to study mechanisms involved in the development of neurotoxicity. Intravenous injection of multiple vincristine doses $(20,75,100$ or $200 \mathrm{mg} / \mathrm{kg})$ in the tail of rats, triggers fast onset of painful neuropathy ${ }^{10}$.

Dose regimen of intravenous $75 \mathrm{mg} / \mathrm{kg}$ (in days $1-5$ and $8-11$, in a total of nine consecutive doses) has been more commonly used for resulting in maximum hyperalgesia with relative absence of motor deficit in most rats. In the fourth day after vincristine administration, there is allodynia with peak of effect in the $11^{\text {th }}$ day. Cumulative dose above $1000 \mathrm{mg} / \mathrm{kg}$ leads to severe sensory and motor changes and very often to death ${ }^{2}$.

Other model able to induce neuropathy was described with a single vincristine dose $(50,100$ or $200 \mathrm{mg} / \mathrm{kg}$ i.v. $)$ and is characterized by allodynia and mechanical hyperalgesia 5 days after injection ${ }^{2}$.

Surgical implant of an osmotic mini-pump in right external jugular vein, with administration of vincristine sulfate $(30 \mathrm{mg} / \mathrm{kg} /$ day) is another proposed model. Vincristine infusion has been associated to the development of mechanical allodynia and allodynia to cold the first week after infusion, with no effect on mechanical and thermal nociception ${ }^{2}$.

\section{Platinum}

Platinum-derived products (oxaliplatin, cisplatin and carboplatin) are agents inhibiting DNA synthesis and the replication by means of cross-links established by the complex.

\section{Cisplatin}

Koning et al. ${ }^{15}$ have studied the development of cisplatin-induced neurotoxicity, although this is a model difficult to reproduce because animals develop renal failure before neurotoxicity. In addition, it is difficult to determine whether neurotoxicity is induced by renal disease or by platinum. Animals' hydration during the model development period and administration of escalating doses of the chemotherapeutic drug decrease this complication. Another model uses $1 \mathrm{mg} / \mathrm{kg}$ three times a week for five weeks.

Another possibility is the administration of 1 to $2 \mathrm{mg} / \mathrm{kg}$ cisplatin once a week for nine weeks, leading to the development of peripheral neuropathy $y^{2,16}$. Other models with different doses and administration regimens have been described in the literature.

Mechanical and thermal to cold allodynia and mechanical and thermal hyperalgesia were documented with no signs of motor dysfunction.

\section{Oxaliplatin}

The toxicity profile of this drug is favorable as compared to its antecessors, that is, less nephrotoxicity, ototoxicity and hematotoxicity. However, it also induces peripheral sensory toxicity. Cavaletti et al. ${ }^{17}$ have observed electrophysiological changes after two cumulative oxaliplatin doses ( 36 and $48 \mathrm{mg} / \mathrm{kg}$ ) inducing slower sensory nerves conduction velocity due to injuries in dorsal root ganglion neuronal cells $s^{2}$.

Other more recent model of oxaliplatin-induced neuropathy with single dose infusion was developed in the attempt to reproduce pain signals which are observed after administration of a single oxaliplatin dose in patients with metastatic colorectal cancer. A single oxaliplatin dose varying from 3 to $12 \mathrm{mg} / \mathrm{kg}$ is administered ${ }^{2}$. Mechanical and thermal to cold allodynia, and mechanical and thermal hyperalgesia were documented with no sign of motor dysfunction. 


\section{Taxanes}

Taxanes improve life expectancy of lung, head and neck, breast and ovary cancer patients. They affect sensory neurons and especially nervous fibers conducting vibration and proprioception sensations.

Taxanes, especially paclitaxel, are agents promoting the union of microtubules as from tubulin dimers, stabilizing them and preventing their depolymerization. This interferes with the dynamic of physiologic reorganization of the network of microtubules, which is essential for vital cell functions ${ }^{2,16}$.

\section{Paclitaxel}

Intraperitoneal 1 to $2 \mathrm{mg} / \mathrm{kg}$ in rats promotes signs of hyperalgesia without systemic toxicity signs. Paclitaxel administered in four alternate days, with cumulative dose of 4 or $8 \mathrm{mg} / \mathrm{kg}$ induces peripheral neuropathy characterized by allodynia to cold, long lasting mechanical allodynia and sciatic nerve endoneural edema. Changes in pain threshold are observed in the fifth day of paclitaxel administration and persist for 3 weeks after the last dose.

Animals treated with vincristin and paclitaxel have mechanical hypersensitivity and hypersensitivity to cold, but few, if any, hyperalgesia to warmth. Models using higher paclitaxel doses (cumulative dose of $80 \mathrm{mg} / \mathrm{kg}$ ) induce thermal hypoalgesia, indicating loss of thermal sensitivity ${ }^{2,16}$.

Loss of pain sensation, morphological abnormalities, neurophysiologic disorders and motor function changes may be well studied with the model with higher doses, because these changes are uncommon or absent in models with low doses of paclitaxel ${ }^{16}$. However, severe autonomic deficits and neurophysiologic abnormalities are drawbacks of the high cumulative dose model.

\section{Docetaxel}

The model of docetaxel-induced neuropathy consists of injection of 5, 10 or $12.5 \mathrm{mg} / \mathrm{kg}$ during four weeks. Animals present slower neural conduction velocity, changes in thermal thresholds and degeneration of skin and paw nerves ${ }^{2}$.

\section{Cancer-induced neuropathies ${ }^{18}$}

An animal model of NP in cancer was developed in mice, where tumor growth is induced close to the sciatic nerve. Under anesthesia, right sciatic nerve is exposed in the gluteus and ascites fluid containing 50 thousand of tumor cells is deposited on the nerve. Tumor growth leads to nerve compression and development of thermal and mechanical hyperalgia in the ipsilateral paw. Signs of spontaneous pain and paw licking are observed. However, as the tumor grows, there is mechanical hyposensitivity of the affected limb, while thermal hyperalgesia and spontaneous pain signs persist.

Gradual compression by tumor cells results in injury to both myelinated and unmyelinated fibers.

\section{Alcohol-induced neuropathy}

Animals (rats) receive $6.5 \%$ ethanol every day for 12 weeks. Ethanol doses as from initial concentration of $2.5 \%$ maintained from the first to the third day are progressively and consecutively increased to $4 \%$ from the fourth to the sixth day; to $4.5 \%$ as from the seventh to the $16^{\text {th }}$ day and finally to $5 \%$ from the $17^{\text {th }}$ to the $70^{\text {th }}$ consecutive day. After this 70 -day period, alcohol-containing diet is progressively decreased in three days. Mechanical hyperalgesia is present after 12 weeks of alcohol consumption and persists after alcohol withdrawal from the $\operatorname{diet}^{2}$.

\section{Other neuropathic pain models $s^{2}$}

Human immunodefficiency virus-induced neuropathy

Sciatic nerve is surgically exposed and impregnated with a cellulose solution containing HIV gp120 proteins. Allodynia and hyperalgesia are developed within three days.

\section{Postherpetic neuralgia}

Cells infected with varicella-zoster virus are injected in paws of rats. Animals develop hyperalgesia behavior three days after infection.

\section{Pyridoxine-induced neuropathy}

Oral administration of 50 to $300 \mathrm{mg} / \mathrm{kg} /$ day pyridoxine for 112 days induces sensory neuropathic abnormalities.

\section{Trigeminal neuralgia}

Anesthetized rats are submitted to the implant of a $21 \mathrm{G}$ cannula in left trigeminal nerve ganglion, through which $10 \mu \mathrm{L}$ of $4 \%$ agar solution is injected to promote nerve constriction without injury.

\section{Orofacial pain}

Formalin is injected in the temporomandibular joint of rats, leading to stereotyped behaviors such as shaking the head, letting the head fall to the injured side, and scratching the affected area of the face.

Acrylamide-induced neuropathy: administration of intraperitoneal acrylamide in doses varying from 20 to $40 \mathrm{mg} / \mathrm{kg}, 3$ days a week for 8 weeks induces neuropathic symptoms.

\section{CONCLUSION}

Since NP is multifactorial, different NP animal models were developed along the years. Models based on peripheral nerves ligation are the most commonly used. From all models described in this review, spared nerve injury is that producing more reproducible behavioral abnormalities for a longer period ( $>6$ months), while chronic sciatic constriction produces less predictable behavioral signs of painful neuropathy.

Hemisection and citokines-induced spinal injury are models of choice to study central pain mechanisms. Other specific models are used to study the specific etiology of the painful condition.

Animal models are critical for the study of NP and much of current knowledge has come from studies with rats and mice. However, few discoveries in basic sciences were effectively translated from rodent models to effective pain therapies. So, behavioral tests with animals should be carefully evaluated ${ }^{19}$.

Further refinements of currently used animal models are needed. Further efforts are needed to determine which animal models may be more predictive, with less investigator biases and with the introduction of more complex and objective evaluation parameters.

\section{REFERENCES}

1. Woolf CJ, Mannion RJ. Neuropathic pain: aetiology, symptoms, mechanisms, and management. Lancet, 1999;353(9168): 1959-64.

2. Jaggi AS, Jain V, Singh N. Animal models of neuropathic pain. Fundam Clin Pharmacol. 2011;25(1):1-28.

3. Smith TJ, Saiki CB. Cancer pain management. Mayo Clin Proc. 2015;90(10):1428-39.

4. Boyette-Davis JA, Walters ET, Dougherty PM. Mechanisms involved in the development of chemoBoyette-Davis JA, Walters ET, Dougherty PM. Mechanisms in
therapy-induced neuropathy. Pain Manag. 2015;5(4):285-96.

5. Basbaum AI. Effects of central lesions on disorders produced by multiple dorsal rhizotomy in rats Exp Neurol. 1974;42(3):490-501.

6. Bennett GJ, Xie YK. A peripheral mononeuropathy in rat that produces disorders of pain sensation like those seen in man. Pain. 1988;33(1):87-107.

7. Seltzer ZR, Dubner R, Shir Y. A novel behavioral model of neuropathic pain disorders produced in Seltzer ZR, Dubner R, Shir Y. A novel behavioral model of neur
rats by partial sciatic nerve injury. Pain. 1990;43(2):205-18.

8. Kim SH, Chung JM. An experimental model for peripheral neuropathy produced by segmental spinal nerve ligation in the rat. Pain. 1992;50(3):355-63.

9. Decosterd I, Woolf CJ. Spared nerve injury: an animal model of persistent peripheral neuropathic pain. Pain. 2000;87(2):149-58.

10. Allen AR. Surgery of experimental lesion of spinal cord equivalent to crush injury of fracture dislocaAllen AR. Surgery of experimental lesion of spinal cord equirad
tion of spinal column. J Am Med Assoc. 1911;57:878-90.

11. Christensen MD, Everhart AW, Pichelman JT, Hulsebosch CE. Mechanical and thermal allodynia in chronic central pain following spinal cord injury. Pain. 1996;68(1):97-107.

12. Hulsebosch CE, Xu GY, Perez-Polo JR, Westlund KN, Taylor CP, McAdoo DJ. Rodent model of chronic central pain after spinal cord contusion injury and effects of gabapentin. J Neurotrauma. 2000;17(12):1205-17.

13. Anderson TE. A controlled pneumatic technique for experimental spinal cord contusion. J Neurosci Methods. 1982;6(4):327-33.

14. Akbarzadeh A, Norouzian D, Mehrabi MR, Jamshidi SH, Farhangi A, Verdi AA, et al. Induction of diabetes by Streptozotocin in rats. Indian J Clin Biochem. 2007;22(2):60-4.

15. Koning D, Neijt JP, Jennekens FG, Gispen WH. Evaluation of cis-diamminedichloroplatinum (II) (cisplatin) neurotoxicity in rats. Toxicol Appl Pharmacol. 1987;89:81-7.

16. Garcia-Larrea L, Magnin M. [Pathophysiology of neuropathic pain: review of experimental models and proposed mechanisms]. Presse Med. 2008;37(2 Pt 2):315-40.

17. Cavaletti G, Petruccioli MG, Marmiroli P, Rigolio R, Galbiati S, Zoia C, et al., Circulating nerve growth factor level changes during oxaliplatin treatment-induced neurotoxicity in the rat. Anticancer Res. 2002;22(6C):4199-204.

18. Wacnik PW, Kehl LJ, Trempe TM, Ramnaraine ML, Beitz AJ, Wilcox GL. Tumor implantation in mouse humerus evokes movement-related hyperalgesia exceeding that evoked by intramuscular carrageenan. Pain. 2003;101(1-2):175-86.

19. Sapunar D, Puljak L. What can rats tell us about neuropathic pain? Critical evaluation of behavioral tests used in rodent pain models. Period Biol. 2009;111(2):155-60. 